\title{
EDITORIALS
}

\section{SOME DANGERS IN ANAESTHESIA}

By Now Canadian readers will have received the 76th Annual Report of the Canadian Medical Protective Association.' In it is a report which is of very great importance to all anaesthetists. Briefly it tells of a patient who had suffered permanent brain damage because of the inadvertent administration of nitrous oxide instead of oxygen. The anaesthetist was unfamiliar with the particular anaesthetic machine he was using at the time and the location of the nitrous oxide and oxygen control knobs on its flowmeter assembly. Hence when changes in flows were indicated, he instinctively reached for the site where he was used to finding his gas controls but, their positions being reversed in the particular machine, he cut off the oxygen supply rather than the nitrous oxide. The Committee on Anaesthetic Equipment and Respiratory Technology of the Canadian Standards Association consider a standard sequence of gases in flowmeters a matter of such immediate urgency that they have caused the Association to circularize interested organizations and Provincial Health Departments in advance of the publication of a "Standard of Performance of Anaesthetic Machines", now practically completed. The intention is that uniformity in the location of the vital oxygen controls be achieved with the greatest speed possible so that catastrophies like the one described above may not repeat themselves. The slogan "Oxygen is Right" has been adopted to acquaint users with the recommendation that the oxygen control knob on machines used in Canada should be on the right side (downstream) of flowmeter assemblies. It is, of course, realized that this will require a period of adjustment on the part of those who have been accustomed to the oxygen flowmeter being to the left of other gases. The downstream position was adopted after weighing all the pros and cons, because of the additional safeguard this position confers in case of an accidental leak within the flowmeter assembly itself. Should this occur, anaesthetic gases, not oxygen, will be lost, whereas if the oxygen were situated upstream, the prime loss would be that of oxygen. ${ }^{2}$ Thus uniformity in the location of the oxygen control carries with it the incidental benefit of eliminating one additional potential hazard. It is a further requirement in the standard that the oxy-

\section{DANGERS EN ANESTHESIE}

Les Membres de l'Association Canadienne de Protection Médicale ont récemment reçu leur copie du rapport 1976. Ce rapport fait état d'un cas de grand intérêt pour tous les anesthésistes. C'est celui d'un patient chez qui un dommage cérébral permanent a été causé par l'administration accidentelle de protoxyde d'azote alors que l'anesthésiste croyait donner de l'oxygène à son malade.

L'anesthésiste en cause n'étajt pas familier avec l'appareil utilisé. Sur cet appareil la disposition des débitmètres était différente de celle à laquelle i] était habitué et, en voulant modifier ses débits de gaz, il tourna d'instinct ce qu'il croyait être le robinet de protoxyde d'azote et ferma de fait le débit d'oxygène.

Le comité d'équipement anesthésique et de technologie respiratoire tient, avant même la publication des "Normes applicables aux appareils d'anesthésie" qui sont actuellement en préparation, à sensibiliser le monde anesthésique et les ministères provinciaux de la santé sur l'urgence d'uniformiser la disposition des débitmètres sur les appareils d'anesthésie, de façon à ce que l'oxygène se trouve de façon constante à la mème position. II recommande que le débitmètre d'oxygène soit placé à droite des séries de débitmètres (le motto en anglais: Oxygen is right).

Il est bien évident que cette nouvelle disposition va demander à ceux qui sont habitués à trouver l'oxygène à gauche des séries de débitmètres de s'habituer à la nouvelle disposition. Mais la disposition à l'extrême droite a été choisie après avoir pesé le pour et le contre. En effet, une position en aval du débit gazeux apporte une sécurité additionnelle dans les cas où une fuite de gaz existe au niveau de l'assemblage des débitmètres. Dans un tel cas, ce sont des gaz anesthésiques et non l'oxygène qui seront perdus, ce qui est le cas si l'oxygène est situé en amont de la série. ${ }^{2}$ Les normes à paraître exigeront également que le robinet d'oxygène soit d'une forme différente de celle des autres gaz, ce qui contribuera à faciliter les choses à ceux qui devront s'habituer à une nouvelle disposition.

De nombreuses autres possibilités d'accidents existent au niveau des appareils d'anesthésie, dû à la multiplicité des appareils et de l'équipement anesthésique que l'on retrouve dans les salles 
gen control knob be clearly identified by a prescribed shape, different from all other controls. This will assist those who during the period of transition must get used to an unaccustomed flowmeter configuration.

It is well to recognize that the position of the oxygen control mechanism on anaesthetic machines is only one of a large number of potentially hazardous situations which arise from the multitude of equipment and controls which we find in operating rooms throughout the country. One need recall only the confusion which may arise from the fact that machines produced in other countries may not comply with the International Standards Organization's colour code for gases. Another major inconsistency lies in the direction in which flow control valves are made to open and close. Flowmeters for anaesthetic gases and "Tec"-type vaporizers reduce concentration or are closed by clock-wise rotation of the control, whereas Forregger and Dräger vaporizers close anti-clockwise. By the same token where concentrations delivered increase in one case, they are reduced by manipulation in the same direction if another vaporizer is used. ${ }^{3}$ Where else would such confusion be tolerated when it may make the difference between life and death? Many examples of this kind could be given but it would be outside the scope of an editorial. They are all well documented in the literature. Suffice it to say here that the standard on anaesthetic machines, when it is published in the near future, deserves study by all anaesthetists who then should insist that all new equipment purchased thereafter comply with all provisions of the standard. While conversion of existing equipment would be ideal it is impractical because of the prohibitive cost implications. One would urge, however, immediate conversion of all machines in service to "Oxygen is Right". There can be no justification to exposing patients to danger from this particular source, since conversion is relatively inexpensive and easily carried out by manufacturers.

G.M. WYaNT d'opération de notre pays. Un premier exemple est celui des appareils produits dans d'autres pays et qui peuvent ne pas être conformes au code de couleur's pour les gaz préconisé par l'Organisme International des Standards. Un second exemple est la direction dans laquelle il faut tourner la valve pour ouvrir ou fermer un débit gazeux. Ainsi, les robinets des débitmètres et les appareils du genre Fluotec-Pentec, etc. s'ouvrent en toumant dans le sens des aiguilles d'une montre, alors que les vaporisateurs Dräger et Foregger s'ouvrent dans l'autre sens. Une rotation dans un sens augmente la concentration d’agent anesthésique dans le premier cas el la diminue dans l'autre. ${ }^{3}$ Dans quel autre domaine tolérerait-on une telle confusion qui peut faire la différence entre la vie et la mort?

Beaucoup d'autres exemples pourraient être donnés, mais dépasseraient les cadres d'un éditorial. Ils sont tous bien documentés dans la littérature.

On comprendra l'importance pour tous les anesthésistes de se faire un devoir d'étudier attentivement les "Normes s'appliquant aux appareils d'anesthésie" qui doivent ètre publiées prochainement. Ils devraient dans l'avenir insister pour que tout nouvel équipement anesthésique acheté soit conforme aux normes préconisés.

L'uniformisation de tout l'équipement en service actuellement serait l'idéal, mais elle est peu facile à réaliser à cause des coûts prohibitifs. L'on recommande cependant fortement la conversion, immédiate de tous les appareils en usage de façon à uniformiser la location à droite de l'oxygène dans les débitmètres en série. Une telle modification partielle aux appareils est facile pour les manufacturiers et d'un coût relativement peu élevé. Dans les circonstances, il serait inexcusable d'exposer des patients à une catastrophe du genre de celle rapportée par l'Association de Protection Médicale Canadienne.

G.M. WYANT

\section{REFERENCES}

1. Brown, F.N. \& HiLtoN, J.H.B. Inadvertence in anaesthesia leading to disaster. 76th Annual Report, Canadian Medical Protective Association, pp. 15-18 (June 1977).

2. Eger II, E.I., Hylton, R.R., IRWIN, R.H., AND GUADAGNI, N. Anesthetic flowmeter sequence. A cause for hypoxia. Anesthesiology 24 3: 396-397 (May-June, 1963).

3. Rendell-Baker, L. Some gas machine hazards and their elimination. Anesth., Analg. $55 /: 26-33$ (Jan.-Feb., 1976). 